Original Paper

doi $\underline{10.15826 / \text { recon.2019.5.2.007 }}$

\title{
Sino-Russian environmental cooperation: past, present, and future
}

\author{
Q. Chen \\ Institute Russia of Academy of Social Sciences of Heilongjiang Province, Harbin, China; \\ e-mail:284748191@qq.com
}

\begin{abstract}
In order to address vital environmental issues, China and Russia have established a set of cooperation mechanisms, such as the Sub-Committee on Environmental Protection of the Regular Meeting of the Prime Ministers of China and Russia. There is currently a multi-level environmental cooperation system between the two countries. In recent years, China and Russia have strengthened their ecological cooperation and have achieved certain results in the conservation of cross-border water resources and establishment of transboundary nature reserves. There are still, however, many problems to handle such as the discrepancies in legislation and the limited character of investment each of the countries is willing to make into environmental protection. Therefore, as the article shows, it is necessary to formulate a unified regulatory framework; to establish a resource protection zone; to enhance joint monitoring of the water quality in transboundary rivers as well as soil and air quality in adjacent areas; and, finally, to raise public awareness in both countries of environmental security and nature conservation. In 2017, Russia hosted the Year of Ecology, which was a good opportunity for both countries to promote information exchange and cooperation in the sphere of joint monitoring and governance, environmental legislation, and ecological education.
\end{abstract}

\section{KEYWORDS}

China, Russia, environmental cooperation, Year of Ecology

\section{FOR CITATION}

Chen Q. (2019) Sino-Russian environmental cooperation: past, present, and future. R-economy, 5(2), 61-70. doi: $10.15826 /$ recon.2019.5.2.007

\section{Китайско-Российское экологическое сотрудничество: прошлое, настоящее и будущее}

\author{
Ц. Чень \\ Институт России Академии общественных наук провинции Хэйлунизян КНР, Харбин, Китай, \\ e-mail:284748191@qq.com
}

\begin{abstract}
АННОТАЦИЯ
Для решения насущных экологических проблем Китай и Россия создали ряд механизмов сотрудничества, таких как Подкомитет по охране окружающей среды Регулярной встречи премьер-министров Китая и России. В настоящее время между двумя странами существует многоуровневая система экологического сотрудничества. В последние годы Китай и Россия укрепили свое экологическое сотрудничество и достигли определенных результатов в сохранении трансграничных водных ресурсов и создании трансграничных природных заповедников. Однако все еще остается много проблем, таких как несоответствия в законодательстве и ограниченный характер инвестиций, которые страны готовы внести в охрану окружающей среды. Поэтому, как показано в статье, необходимо сформулировать единую нормативно-правовую базу; создать ресурсную охранную зону; усилить совместный мониторинг качества воды в трансграничных реках, а также качества почвы и воздуха в прилегающих районах; и, наконец, повысить осведомленность общественности в обеих странах об экологической безопасности и сохранении природы. В 2017 году в России прошел Год экологии, который стал для обеих стран хорошей возможностью содействовать обмену информацией и сотрудничеству в области совместного мониторинга и управления, экологического законодательства и экологического образования.
\end{abstract}

\section{КЛЮЧЕВЫЕ СЛОВА}

Китай, Россия, экологическое сотрудничество, год экологии

\section{ДЛЯ ЦИТИРОВАНИЯ}

Chen Q. (2019) Sino-Russian environmental cooperation: past, present, and future. R-economy, 5(2), 61-70. doi: 10.15826/recon.2019.5.2.007 


\section{Introduction}

China and Russia are currently experiencing the best period of history in their relationship, both in terms of political and economic cooperation. China and Russia have a common border separated by the Amur, Songhua River and Wusuli River and Xingkai Lake. Shared water resources determine the need for cooperation between the two countries in the sphere of environmental protection. In addition, there is also a land boundary, which is more than 4,300 kilometers long. Therefore, both countries face a number of environmental problems associated with the conservation of forests, protection of wildlife and plant life, prevention of air pollution and so on. These problems are a part of large-scale global issues such as the global warming and resource depletion.

Like in many other countries in the world, the environmental conditions in China and Russia leave much to be desired. According to the 2017 Bulletin on the State of Ecological Environment, 239 cities in the country's 338 prefecture-level cities or $70.7 \%$ do not meet the air quality requirements ${ }^{1}$. In Russia, the amount of recycled and neutralized waste increased by 1.9 times compared to 2010. In 2017, the total amount of solid chemical waste exported from Russia was 274.4 million cubic meters, $16.6 \%$ more than in 2010. In 2017, the amount of municipal solid waste exported to waste treatment plants reached 27.9 million cubic meters, accounting for $10 \%$ of the total municipal solid waste ${ }^{2}$. Thus, it can be seen that both China and Russia are facing severe environmental pressures.

\section{Methodology}

The study uses methods of comparative analysis, by focusing on both quantitative and qualitative indicators to show the similarities and differences in China's and Russia's approach to environmental protection.

It should be noted that comparative studies on ecology and environmental protection in China consider cases of other countries trying

2017 China Ecological Environment Bulletin (2018). Retrieved from: http://www.mee.gov.cn/gkml/sthjbgw/qt/201805/ t20180531 442212.htm (Accessed 1 October 2018)

${ }^{2}$ Ministry of Natural Resources of the Russian Federation: State Report "On the condition and protection of environment in the Russian Federation in 2017" (December 2018). Retrieved from: https://nangs.org/analytics/ minprirody-rossii-gosudarstvennyj-doklad-o-sostoyanii-i-ob-okhrane-okruzhayushchej-sredy-rossijskoj-federatsii-pdf (Accessed 1 October 2018) to solve similar problems. For example, much attention is paid to water issues in the studies of Liya Su, Jingling Liu, Per Thorsø Christensen [1], Shaofeng Jia, Yuanyuan Sun, Jesper Svensson, Maitreyee Mukherjee [2]. Kai-Yi Zhouand and William R. Sheate compare Chinese legislation with that of Northern European countries [3]. It should be noted here that similar studies on Russian environmental problems were conducted by Russian researchers.

After the end of the Cold War, the traditional geopolitical pattern and political relations underwent tremendous changes. The security issue has expanded from the traditional military and political spheres to economic, social, and environmental fields [4]. Environmental security, especially cross-border environmental security issues, is particularly prominent in geopolitical relationships. As geopolitical and economic relations between China and the neighbouring country were developing, more and more attention started to be given to cross-border environmental security as a part of national environmental security, for example, protection of cross-border water resources [5-7] and joint construction and coordination management of cross-border nature reserves [8;9].

China's environmental problems are discussed both nationwide [10], and across entire Asia [11], since they greatly affect the neighboring countries. Some studies consider a range of tools to address these problems, in particular by changing taxation [12;13].

Environmental issues faced by Russia are discussed by Russian and European researchers $[14 ; 15]$. Russian researchers often approach environmental problems by focusing on questions of sustainable development and conduct their analysis on the national and interregional levels rather than on the level of international cooperation.

This study compares the Russian and Chinese approaches to solving environmental problems and discusses the prospects of interstate cooperation. The purpose of the study is to outline the prospects for Russian-Chinese cooperation and propose measures to strengthen this relationship. In order to achieve this goal, we need to analyze the current state of Sino-Russian environmental cooperation; identify the possible impediments; and devise recommendations for handling them. The hypothesis behind this study is that the environmental policies of China and Russia should be based on cross-border cooperation. 
The structure of the article is based on the "point-by-point" scheme, that is, for each of the given parameters, information about one country is first provided, followed immediately by the description of the other country. After discussing the parameters, the findings are presented and suggestions are made to address the problems.

\section{Natural resources of Russia and China}

Russia is known to be a rich country, abundant in resources such as oil, natural gas, timber, minerals and fresh water. Although China's resources can also be sufficient, due to the rapid economic development in recent years, the environment has suffered from serious pollution and damage. For example, if we consider water resources, China's per capita freshwater resources are much lower than Russia's, but the average annual water consumption is significantly higher than that of Russia (see Table 1). It can be said that compared with Russia, China faces more serious problems in environmental protection and sustainable development. On October 18, 2017, Chinese President Xi Jinping emphasized in his report that "constructing ecological civilization is a millennium plan for the sustainable development of the Chinese nation. It is necessary to establish and practice the concept of green mountains. The basic national policy of conserving resources and protecting the environment treats the ecological environment as life" ${ }^{3}$ China has turned sustainable development into a basic national policy and decided to contribute to the world's environmental security.

Russia's and China's freshwater resources and their use

\begin{tabular}{|c|c|c|c|c|c|}
\hline & \multirow{2}{*}{$\begin{array}{l}\text { Fresh- } \\
\text { water } \\
\text { reserves } \\
\text { per cap- } \\
\text { ita, m³ }\end{array}$} & \multirow[b]{2}{*}{$\begin{array}{c}\text { Annual } \\
\text { average } \\
\text { fresh wa- } \\
\text { ter con- } \\
\text { sumption, } \\
\text { billion } \mathbf{m}^{3}\end{array}$} & \multicolumn{3}{|c|}{ Freshwater use (\%) } \\
\hline & & & $\begin{array}{l}\text { agri- } \\
\text { cul- } \\
\text { ture }\end{array}$ & $\begin{array}{c}\text { indus- } \\
\text { try }\end{array}$ & $\begin{array}{l}\text { house- } \\
\text { hold } \\
\text { con- } \\
\text { sump- } \\
\text { tion }\end{array}$ \\
\hline Russia & 29.013 & 47,9 & 15 & 69 & 16 \\
\hline China & 2.062 & 594,2 & 64 & 22 & 13 \\
\hline
\end{tabular}

Source: The table is based on the data of the National Statistics Office of the Russian Federation. Retrieved from: http://www. gks.ru/bgd/regl/b18 39/Main.htm (Accessed 1 October 2018)

At present, the comprehensive strategic partnership between China and Russia has entered the "best period in history". The integration of the

3 Xi Jinping. (2017-10-28) Decisive victory to build a welloff society in an all-round way to win the great victory of socialism with Chinese characteristics in the new era. People's Daily, 001.
Belt and Road Strategy and the Eurasian Economic Alliance has become a top priority in the comprehensive strategic partnership between China and Russia. It will promote social and economic development of the two countries and their neighbours. As regional powers, China and Russia have always been committed to maintaining regional security and promoting regional development. Cooperation in the field of environmental conservation is among the most important areas.

\section{History and the current status of Sino-Russian environmental cooperation}

Sino-Russian environmental cooperation began in the 1980s (see Table 2 below). This cooperation first focused on the protection of the boundary rivers. On October 23, 1986, China and the Soviet Union signed the Agreement on Water Resources Management. On May 27, 1994, China and Russia signed the cooperation agreement in the field of conservation, utilization and reproduction of aquatic resources in the Heilongjiang and Wusuli Rivers; on April 25, 1996, the Agreement on the Establishment of a Forbidden Fishing Area between China and Russia in Xingkai Lake was signed [16]. The cooperation between China and Russia began to expand when in May 1994, the Agreement on Environmental Protection Cooperation between the Government of the People's Republic of China and the Government of the Russian Federation was signed. In November 1997, China and Russia signed the "Joint Statement", which emphasized the importance of environmental cooperation and described the responsibilities of the two countries to prevent cross-border pollution and ensure rational and economical use of natural resources (including transboundary water resources) $)^{4}$.

A turning point in the Sino-Russian environmental cooperation became the Songhua River water pollution incident in 2005. On November 13, 2005, the explosion of the double-benzene plant of Jilin Petrochemical Company in China caused an environmental disaster on the Songhua River, which seriously affected the residents' living conditions in the adjacent areas of the two countries. In order to protect people from pollution, the two countries decided to further strengthen

${ }^{4}$ China Environmental News reporter talks Li Ping, director of the Environmental Protection Department of Heilongjiang Province - wins understanding and trust by hard work (2010). Retrieved from: http://www.hljdep.gov.cn/zmhd/ zxft/2010/02/10271.html (Accessed 1 October 2018) 
their cooperation in monitoring of the water quality in the rivers. Since then, the two governments have begun to address and pay more attention to the importance of environmental cooperation. In 2006, China and Russia signed the "Sino-Russian Joint Monitoring Plan for Water Quality of Transboundary Waters", which expanded joint monitoring to cross-border water in the Ergun, Heilongjiang, Wusuli River, Suifenhe and Xingkai Lakes. Thus, water monitoring was raised from the local to national level: the corresponding national departments of the two countries started to exchange information about their monitoring results.

The two countries also established the Environmental Protection Subcommittee within the Chinese-Russian Prime Ministers' Regular Meeting Committee in the same year. Thus, the highest level of environmental cooperation between the two countries was established. Since then, the countries have been taking turns to hold meetings of the Sub-Committee. Within the framework of the Sub-Committee, the two countries are now closely cooperating in the three core areas, including emergency response to pollution and environmental disasters; establishing transboundary nature reserves and biodiversity conservation; cross-border water monitoring and protection.

In addition, cooperation is now realized on the level of research organizations and research groups: since 2008, in Heihe City, Heilongjiang
Province, there has been held "Heilongjiang Heihe Sino-Russian Forestry Ecological Construction Academic Forum". In 2013, the "Russian-Chinese Forum on the Conservation and Rational Use of Forest Resources" was held for the first time in the Amur region. These two local forums are aimed at enhancing scientific research in the sphere of environmental conservation ${ }^{5}$.

China and Russia have launched environmental cooperation programs within the framework of international organizations such as the SCO and BRICS. In September 2013, the China-Shanghai Cooperation Organization Environmental Protection Cooperation Center was established. The center is committed to implementing the consensus of the Shanghai Cooperation Organization Leaders Meeting and promoting environmental protection cooperation and exchanges between China and Shanghai Cooperation Organization member states. China and Russia rely on China-Shanghai Cooperation Organization Environmental Protection Cooperation Center to carry out multilateral ecological cooperation under the framework of the SCO and BRICS and work together to solve global environmental problems.

Both countries have established a mechanism of environmental cooperation between Chinese and Russian enterprises. In 2015, the China-Russia Friendship Peace and Development Commit-

\footnotetext{
${ }^{5}$ Heihe Daily, June 13, 2013, version 001.
}

Regulations and agreements on the environmental cooperation between Russia and China

Table 2

Regulations and agreements

Sino-Russian Cooperation Agreement on the Protecting the aquatic resources of the Heilongjiang and the Wusuli River; Protection, Utilization and Reproduction of Aquatic Resources in the Heilongjiang and Ussuri Rivers (signed on 27 May, 1994)

Sino-Russian Agreement on Xingkai Lake Nature Reserve (signed on 25 April, 1996)

Sino-Russian Joint Statement (signed in November 1997)

Joint Monitoring Plan for Sino-Russian Transboundary Water Quality (signed on 2 June, 2006)

Sino-Russian Transboundary Water Use and Protection Cooperation Agreement (signed on 29 January, 2008) promoting utilization and reproduction of aquatic resources in the two boundary rivers

Protecting flora and fauna in nature reserves; promoting bilateral cooperation in the sphere of environmental conservation and sustainable use of natural resources;

monitoring and research of natural ecosystems;

raising awareness of the purpose and meaning of nature conservation among citizens of both countries

Prevention of cross-border pollution;

Promotion of sustainable use of natural resources (including transboundary water resources)

Joint monitoring of the Ergun River, Heilongjiang River, Wusuli River,

Suifen River and Xingkai Lake;

Monitoring of water quality in Sino-Russian transboundary waters on the national level;

Monitoring to be carried out by the corresponding national departments

Defining the use, protection and detection of transboundary water bodies; Stipulation of the relevant responsibilities of the two governments, including responsibilities to inform each other about the situation in the boundary river waters, facts of water pollution and so on, and the responsibilities to take measures when necessary 
Joint Chinese-Russian events in the field of environmental protection in 2017

\begin{tabular}{|l|l|}
\hline \multicolumn{1}{|c|}{ Area } & \multicolumn{1}{c|}{ Event description } \\
\hline $\begin{array}{l}\text { Bird protection and wildlife survey work (April, } \\
\text { 2017) }\end{array}$ & $\begin{array}{l}\text { Bagua Island National Nature Reserve and Russias Basdak Nature Reserve } \\
\text { monitored endangered birds, such as the Oriental white stork and great egret }\end{array}$ \\
\hline Bird and fish protection & $\begin{array}{l}\text { Researchers from China and Russia jointly conducted wildlife inspections } \\
\text { in Honghe Nature Reserve }\end{array}$ \\
\hline Bird protection (April, 2017) & The First Xingkai Lake International Love Bird Festival \\
\hline Environmental protection (October, 2017) & $\begin{array}{l}\text { Honghe Reserve and Bastak Reserve jointly published the album "People } \\
\text { and Nature" }\end{array}$ \\
\hline $\begin{array}{l}\text { Protection of biodiversity and promotion of } \\
\text { environmental security (29 May - 3 June, 2017) }\end{array}$ & “Belt and Road"Baikal Eco-Forum \\
\hline Research of fauna and flora & $\begin{array}{l}\text { Background survey of animals and plants in Xingkai Lake and the Song } \\
\text { Acha River Basin }\end{array}$ \\
\hline
\end{tabular}

tee added an ecological council, which provided an important communication channel for civil cooperation in this sphere.

\section{Achievements in Sino-Russian environmental cooperation}

Within the multi-level Sino-Russian environmental cooperation system, both countries have managed to achieve certain results in protecting cross-border water resources, establishing transboundary nature reserves and ensuring biodiversity conservation ${ }^{6}$. In 2013, experts from the Chinese Academy of Sciences and Changbai Mountain Reserve visited the "Far East Leopard Habitat" Nature Reserve in Russian Primorye and planned to sign an agreement with the Russian partners to protect the north-eastern tiger. Russia and China's future plans include the establishment of protected areas for protection of the far eastern leopard the north-eastern tiger. At the moment, most of the cooperation is realized in the form of information exchange ${ }^{7}$.

As for biodiversity conservation, the two countries have established four cross-border nature reserves: Xingkai Lake Nature Reserve, Sanjiang Nature Reserve, Bagua Island Nature Reserve and Honghe Nature Reserve [17]. The Sino-Russian cross-border nature reserve cooperation plan is to meant to intensify the information exchange and improve the level of cooperation for protection of rare animals and plants. Table 3 shows some of the joint environmental activities in 2017.

${ }^{6}$ China Environmental News reporter talks Li Ping, director of the Environmental Protection Department of Heilongjiang Province - wins understanding and trust by hard work (2010). Retrieved from: http://www.hljdep.gov.cn/zmhd/ zxft/2010/02/10271.html (Accessed 1 October 2018)

Russia and China agreed to protect tigers together (2013). Retrieved from: http://www.cntour2.com/viewnews/2013/01/25/ xCv0qEO4XrigDVK1MBd30.shtml (Accessed 1 October 2018)

\section{Problems in Sino-Russian environmental cooperation}

Russia and China have a number of similar problems of economic development, they also have comparable goals and conditions and can, therefore, build their interaction in all areas on a solid foundation of good neighbourly relations [18]. In recent years, the rapid economic development and industrialization have put enormous pressure on the environment of the neighboring regions of the two countries. The intensity of ecological protection measures and the ability of ecological restoration do not compensate for the deterioration of the natural environment.

The first problem to be considered here is the limited investment both countries make into environmental protection. According to the experience of developed countries, the national environmental protection investment generally accounts for more than $2 \%$ of GDP, and 3\% can bring about significant improvements in the sphere of environmental conservation. For nearly ten years, China's environmental protection investment has been below $2 \%$ of GDP, and it was below 1.5\% for a long time. Russia's environmental protection investment accounts for less than 1\% of GDP. Therefore, there is a huge gap between Chinese and Russian investment and that of developed countries.

The second problem concerns water resources. The Heilongjiang, Wusuli River, Xingkai Lake and Suifen River in Heilongjiang Province are adjacent to Russia. The deterioration of water resources will affect the living conditions and socio-economic development in the region and have a serious impact on the climate and ecosystem. In November 2005, the water pollution incident occurred on the Songhua River; in September 2006, yet another incident of water pollution occurred 


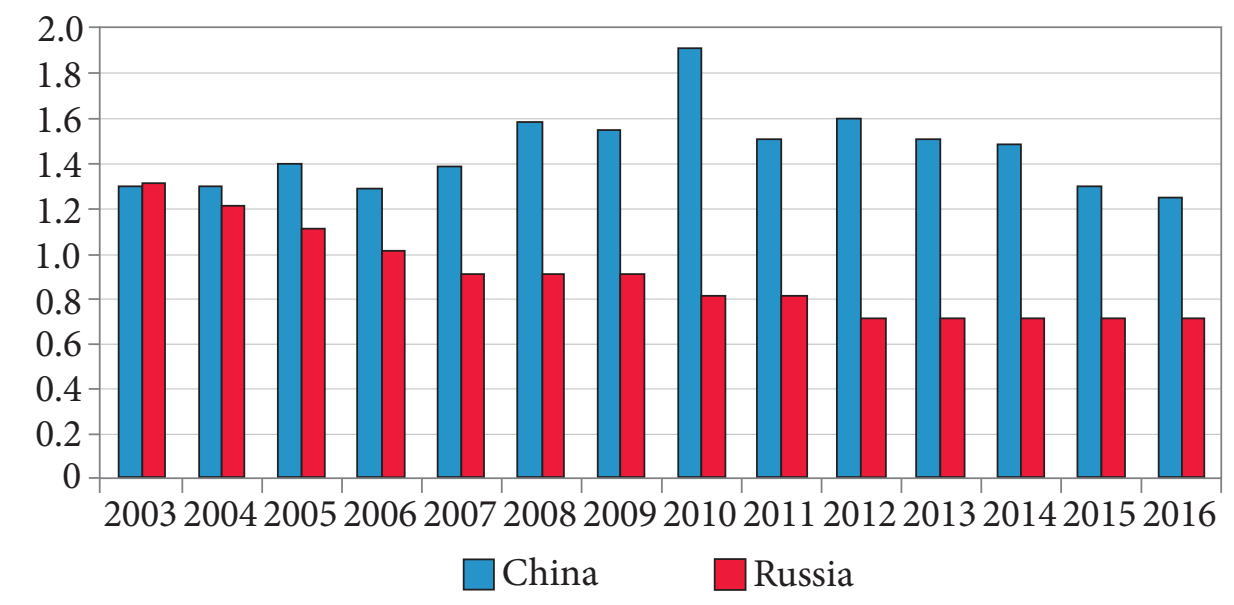

Figure 1. Investment into environmental protection, percentage of GDP, \% (The chart uses the daa of the China Environmental Statistics Yearbook and the National Statistics Office of the Russian Federation)

on the Niuhe River in Jilin; in November 2006, the Russian side found that water near the villages in Khabarovsk regions was contaminated with camphor and requested the Chinese side to analyze the concentration of camphor in the waters of the Songhua River and Tongjiang, and to inform the Russian side of the results ${ }^{8}$. These incidents show how vulnerable is the natural environment in the region. After that, China and Russia took some steps to establish joint monitoring of water quality in the boundary rivers and achieved certain results.

Russia and China formulated the "Sino-Russian Joint Monitoring Plan for Cross-border Water Quality”. This plan proposes to conduct joint monitoring of the transboundary waters of the Heilongjiang, Wusuli River, Erguna River, Suifen River and Xingkai Lake. Joint monitoring has been realized since 2007 [19]. However, there are still some problems in the cooperation between the two countries: the number of water tests is insufficient; the water quality related data and boundary river water database need to be improved; the water quality testing standards of the two countries lack uniformity; there is also a lack of a unified information platform and management supervision platform; the differences in management departments and management systems between the two countries lead to a lack of understanding on the responsibilities of the sides and so on.

${ }^{8}$ China Environmental News reporter talks Li Ping, director of the Environmental Protection Department of Heilongjiang Province - wins understanding and trust by hard work (2010). Retrieved from: http://www.hljdep.gov.cn/zmhd/ zxft/2010/02/10271.html (Accessed 1 October 2018)
The third problem is the conservation of forest resources. Forestry resources in the adjacent areas of China and Russia are extremely rich. According to the data of the National Forest Register as of January 1, 2018, the total area of the Russian Federation with forest distribution is 184.45 million hectares, and the forest area is 1,147 million hectares. The areas with the highest forest coverage are the Far Eastern Federal District and the Siberian Federal District. In China, Heilongjiang Province is the main national forest area and a source of timber. As of 2017, the province's forest coverage rate was $47.07 \%$, and forest accumulation was 1.994 billion cubic meters 9 .

The problem of illegal logging in the adjacent regions of China and Russia is really serious and involves severe violations of operating procedures in timber harvesting. The Russian forest area mainly develops logging and paper industries, and the paper industry also causes some serious water pollution and air pollution to the region. Nikola Smatakov, Director of the forest project of the Russian branch of the WWF, said that the Russian timber prices are extremely low: for example, the cost of logging 1 cubic metre of eucalyptus wood in the Far East is only 41 rubles, while the market price may exceed 10 thousand rubles, which leads to inefficient use of resources and people being unwilling to restore the forest area. The ecologist also added that because the regulatory authorities often have incomplete information about forest

${ }^{9}$ Bulletin on the State of the Environment of Heilongiiang Province in 2017 (2018). Retrieved from: http://www.hljdep. gov.cn/hjgl/hjic/hjzkgb/2018/06/19044.html (Accessed 1 October 2018) 
resources and that there is a risk of deforestation, with the amount of illegal harvesting of some valuable tree species (eucalyptus, oak, ash) being twice or more than the legally allowed amount of forest harvesting [8].

The fourth problem is protection of rare animal and plant species. In addition to forest resources, a large part of wetland is located in the area of the Wusuli River Basin and Xingkai Lake. The flora and fauna are very rich, and it is the main habitat of many endangered species and the stopover of migratory birds. So far, Heilongjiang Province has established 250 nature reserves of various types and levels, including 40 at the national level, 84 at the provincial level, 55 at the municipal level, and 71 at the county level, with the total area of 7.9 million hectares. The total area of nature reserves accounts for $16.7 \%$ of the province's total area, and the area of the Heilongjiang River Basin Conservation Area accounts for about $40 \%$ of the total area of the province's nature reserves ${ }^{10}$.

In recent years, the demand for rare animals and plants has increased due to the eating habits of the people of Northeast Asian countries and the improvement of people's living standards. The problem of reduced income and unemployment in the Russian Far East will lead people to take risks and steal rare animals and plants. The old laws and regulations cannot prevent illegal poaching, and the relevant law enforcement departments lack the necessary power and resources, which leads to illegal hunting and theft. There are transfer channels between China and North Korea and rare animals and plants, such as ginseng, the far eastern leopard, lynx, camphor, and leeches, are in a lot of danger.

Therefore, it is imperative to improve environmental cooperation between China and Russia. The environmental problems of China and Russia, especially the problems in the adjacent areas, will inevitably require the two countries to work together to enhance the existing environmental cooperation system and maintain the ecological harmony shared by the two countries.

\section{Prospects for Sino-Russian environmental cooperation}

China and Russia have established a robust system for cooperation in the sphere of environ-

${ }^{10}$ Report on the Sino-Russian Transboundary Nature Reserve and Biodiversity Conservation in Heilongjiang Province in 2016 (2017). Retrieved from: http://www.hljdep.gov.cn/higl/ zrbh/swdyxbhyswaqgl/2017/04/15484.html (Accessed 1 October 2018) mental protection. At the same time, the urgency of environmental issues requires that the two countries should maximize the efficiency of this cooperation.

In 2017, Russia held the Year of Ecology, which included such activities as improvement of environmental legislation, promotion of environmentally friendly technologies, improvement of solid waste treatment methods, establishment of special nature reserves, protection of water, forests, rare animals and other resources, and popularization of ecological education. As a result, 7,000 activities at the federal and regional levels are scheduled to be completed by 2025 , and emissions of air pollutants and river networks have decreased by 284,000 tons per year. A state registry of objects that have a negative environmental impact was created with 87,953 of such objects registered. The national parks Sengileevsky Mountains (Ulyanovsk Region) and Kislovodsky (Stavropol Territory) were established. A large number of events focused on Lake Baikal, including "Eco-Generation" flash mob and the Baikal Ecological Water Forum, attended by more than 1,000 people ${ }^{11}$. The Russian experience of the Year of Ecology has set a good example for China.

\section{Expanding cooperation}

There are a number of areas in which Russia and China can expand their cooperation: for example, the protection of the boundary river and the boundary lake. It is necessary to control the pollution of industrial and agricultural wastewater and domestic sewage; prevent pollution accidents; protect vegetation and wetlands; organize restoration or reforestation projects to guarantee the recovery of forests and grassland in former agricultural areas; enhance joint monitoring and control over the quality of water; improve the database on the quality of water in boundary rivers; organize regular updating and harmonization of water quality testing standards; facilitate information exchange on the state of border rivers; establish a unified information platform and a coordinated supervision platform. There should be created transnational authorities with clearly defined rights and responsibilities, in charge of the protection and control over the environment in the boundary areas.

As for the establishment of transboundary nature reserves and biodiversity conservation,

\footnotetext{
${ }^{11}$ (2017) Results of the Year of Ecology in Russia. Moscow, p. 14.
} 
under the supervision of the Sino-Russian Environmental Protection Sub-Committee, Sanjiang, Honghe, Bagua Island and Xingkai Lake National Nature Reserves in Heilongjiang Province are engaged in active cooperation with Russia. The Sanjiang National Nature Reserve has signed an agreement with Khabarovsk and Jewish Autonomous States to jointly protect the natural environment between the Wusuri River and Heilongjiang River Basin. The Honghe National Nature Reserve promotes Sino-Russian ecological cooperation through the GEF Wetland Project and is committed to the task of biodiversity conservation in protected areas ${ }^{12}$. The two countries can continue to expand their cooperation in testing, scientific research, publicity, resource conservation, eco-tourism, cross-border nature reserves, and so on.

\section{Environmental education}

The Russian government has always attached great significance to the building of ecological culture by focusing on environmental education, especially among younger generations, environmental awareness, and mass communication of environmental information. It is largely this experience that China can learn from. According to the regulations of the Russian Ministry of Education, the environmental education curriculum is compulsory for Russian schools. However, at this stage, China is experiencing serious shortages of qualified teachers, specializing in environmental education and the quality of such education still leaves much to be desired. Therefore, the secondary education system in China should include environmental education in the list of its top priorities, start to provide high quality courses and teaching materials, and guide students to implement the ecological civilization concepts in their daily lives.

Russia also invests into popularization of environmental action and raising environmental awareness. The "Russian Federal Environmental Protection Law" stipulates that "environmental protection legislation and ecological security legislation should be popularized among residents" [20]. The same should be done in China: a flexible and diverse approach should be applied to popularize and publicize relevant laws and policies, to enhance public environmental awareness and

${ }^{12}$ China Environmental News reporter talks to Li Ping, Director of the Environmental Protection Department of Heilongjiang Province (2010). Available at: http://www.hljdep.gov.cn/ zmhd/zxft/2010/02/10271.html (Accessed 1 October 2018) public engagement. Chinese citizens should learn about the eco-friendly technologies and sustainable consumption.

\section{Enforcing environmental legislation}

In Russia, the main principles of environmental legislation are established by the Constitution. The "Russian Federal Environmental Protection Law" adopted in 2002 has the status of the basic law and forms the foundation for other normative documents. The country's environmental policy is described in such documents as "Environmental Protection for 2012-2020", "Strategy of Environmental Security until 2025", and the 'Russian National Environmental Strategy. In addition, there are annual reports issued by the Russian Ministry of Natural Resources and Environmental Protection. The purpose of these reports is to ensure that state authorities, social organizations and the public should be aware of the state of environmental protection, which includes ensuring the rational use of natural resources, restoration of natural resources and implementation of the country's sustainable development strategy [20].

The Chinese side also has some relevant policies. The report of the $19^{\text {th }}$ National Congress pointed out that the reform of the ecological civilization system would be accelerated. The reform includes promotion of "green" development, protection of ecosystems, changes in the system of environmental supervision and measures to address some specific environmental problems. The report also incorporates the principle of "harmonious coexistence of man and nature" into the basic strategy of the country's development. It is planned that by 2035, "there would be some fundamental improvements of the environment and the goal of beautiful China would be realized".

The newly revised Environmental Protection Law of the People's Republic of China came into force on January 1, 2015. Although Russia's Environmental Law has some differences from China's Environmental Protection Law, they also have quite a lot in common: for example, both laws establish some basic rules and principles of environmental protection, appoint specific government agencies in charge of environmental management. However, many places in the "Environmental Protection Law of the People's Republic of China" are not as comprehensive as the Russian law. For example, unlike its Russian counterpart, the Chinese law provides no description of the basic system of environmental protection, instead some 
parts dealing with this topic are scattered across different articles of the law. In addition, China's law does not mention ecological identification, international cooperation and other relevant topics. Therefore, China can learn from Russia's experience of environmental legislation.

\section{Conclusion}

In today's rapidly developing world, air, water and soil pollution is becoming one of the most serious global problems. Many countries are now trying to develop and implement various strategies in the sphere of environmental cooperation. China and Russia share a borderline of more than 4,000 kilometers and have common rivers, which means that there are some mutual expectations and responsibilities concerning nature conservation and sustainable development.

As regional powers, China and Russia have been committed to maintaining regional security and promoting regional development. Environmental protection is one of the key areas of cooperation between the two countries. Some significant results have already been achieved in the sphere of protection of cross-border water resources, creation of transboundary nature reserves and ensuring biodiversity conservation, for example, the two countries have established twelve transboundary protected areas. Various types of cooperation agreements at the national and local levels have been signed, cooperation institutions for information exchange and monitoring have been founded. Of course, there are still many problems that need to be addressed such as the lack of a unified information platform and supervision platform, relevant databases, protection of rare animal and plant species. The 2017 Year of Ecology in Russia provides China with some valuable lessons to learn from.

In recent years, the Chinese government has attached great importance to environmental protection. Under the guidance of Xi Jinping, China is putting a lot of effort into promotion of sustainable development methods, prevention and control of air, water and soil pollution. There are hopes that in the future, the cooperation between China and Russia will be carried out under the framework of the "Belt and Road" Initiative and the Eurasian Economic Union.

In summary, we believe that although the cooperation between China and Russia in the sphere of environmental protection is not as close as their economic cooperation, it has made certain progress in recent years. There is a growing awareness in both countries that this cooperation is mutually important.

\section{References}

1. Su, L., Liu, J., \& Christensen, P. (2010). Comparative study of water resource management policies between China and Denmark. Procedia Environmental Sciences, 2, 1775-1798. DOI: 10.1016/j. proenv.2010.10.190

2. Jia, S., Sun, Y., Svensson, J., \& Mukherjee, M. (2016). Comparative analysis of water rights entitlements in India and China. Water Policy, 18(S1), 50-67.

3. Zhou, K. Y., \& Sheate, W. R. (2009). Comparative analysis of SEA legal requirements and institutional structure in China (Mainland), Canada and the UK (England). Journal of Environmental Assessment Policy and Management, 11(4), 387-426. DOI: 10.1142/S1464333209003427

4. Liu, Y. L., Ge, Y. J., Hu, Z. D., \& CAO, Y. (2013). Tendency of international security study and its revelations to geosecurity study in China. World Regional Studies, 22(1), 12-21.

5. Feng, Y., He, D. M., \& Li, Y. G. (2013). Key indicators and the characteristics of trans-boundary water allocation based on international treaties. Acta Geographica Sinica, 68(3), 357-364. (In Chinese)

6. He, D. M., Liu, C. M., Feng, Y., Hu, J. M., Ji, X., \& Li, Y. G. (2014). Progress and perspective of international river researches in China. Acta Geographica Sinica, 69(9), 1284-1294. (In Chinese)

7. Jiang, B. L., Geng, L. H., Shen, F. X., Tian, Y., \& Chen, Y. W. (2011). Connotation of the transboundary river security. Water Conservancy Science and Technology and Economy, 17(12), 25-27. (In Chinese)

8. Shi, L., Li, D., Chen, L., \& Zhao, Y. (2012). Transboundary protected areas as a means to biodiversity conservation. Shengtai Xuebao/Acta Ecologica Sinica, 32(21), 6892-6900. DOI: 10.5846/ $\underline{\text { stxb201110061453 (In Chinese) }}$

9. Wang, W., Tian, Y., Chang, M., \& Li, J. S. (2014). A review of transboundary protected areas network establishment. Acta Ecologica Sinica, 34(6), 1391-1400. (In Chinese) 
10. Khan, M., \& Chang, Y. C. (2018). Environmental challenges and current practices in China A thorough analysis. Sustainability, 10(7), 2547. DOI: $10.3390 /$ su10072547

11. Schreurs, M. A. (1998). An Analytic Framework for a Comparative Study of Environmental Governance in Asia. In: Yohei Harashima (ed.). Environmental Governance in Four Asian Countries. Shonan: Japan, IGES.

12. Wu, J., \& Tal, A. (2018). From Pollution Charge to Environmental Protection Tax: A Comparative Analysis of the Potential and Limitations of China's New Environmental Policy Initiative. Journal of Comparative Policy Analysis: Research and Practice, 20(2), 223-236.

13. Ross, L. (1984). The implementation of environmental policy in China: A comparative perspective. Administration \& Society, 15(4), 489-516.

14. Fiorino, T., \& Ostergren, D. (2012). Institutional instability and the challenges of protected area management in Russia. Society \& Natural Resources, 25(2), 191-202. DOI: $\underline{10.1080 / 08941920.2011 .603142}$

15. Newell, J. P., \& Henry, L. A. (2016). The state of environmental protection in the Russian Federation: a review of the post-Soviet era. Eurasian Geography and Economics, 57(6), 779-801. DOI: 10.1080/15387216.2017.1289851

16. Ren T. (2010). Research on Ecological Security Cooperation in Adjacent Areas between China and Russia. Siberian Studies, 1, 89-94.

17. Yunying C. (2018). He Fang, Analysis of the Status Quo and Prospects of Sino-Russian Ecological Cooperation. Northeast Asian Economic Research, 6, 46. (In Chinese)

18. Maximova A. V. (2016) Russian-Chinese environmental cooperation as a factor in economic development. In: Taylakov O. V. (ed.) Paper presented at the All-Russian scientific-practical conference of young scientists with international participation: Russia is young, April 19-22, 2016, Kemerovo (pp. 464). Kemerovo: T.F. Gorbachev Kuzbass State Technical University. Retrieved from: http://science.kuzstu.ru/wp-content/Events/Conference/RM/2016/RM16/pages/Articles/ IEU/37/45.pdf (Accessed 1 October 2018) (In Russ.)

19. Aixin W. (2015). Suggestions on Countermeasures for Ecological Security Cooperation between China and Russia Adjacent to the Basin. Siberian Research, 4, 33.

20. Yingmei L., Changwei P. (2017). Countermeasures and Measures for Ecological Management in Russia. Contemporary World, 3, 70. (In Chinese)

\section{Author}

Qiujie Chen - Researcher, Institute Russia of Academy of Social Sciences of Heilongjiang Province (150018, China, Harbin, Yui, 501); e-mail: 284748191@qq.com

ARTICLE INFO: received January 22, 2019; accepted May 30, 2019

\section{Информация об авторе}

Чэнь Цюцзе - научный сотрудник Института России Академии общественных наук провинции Хэйлунцзян (150018, КНР, г. Харбин, ул. Юи, 501); e-mail: 284748191@qq.com

ИНФОРМАЦИЯ О СТАТЬЕ: дата поступления 22 января 2019 г.; дата принятия к печати 30 мая 2019 г.

This work is licensed under a Creative Commons Attribution 4.0 International License

Эта работа лицензируется в соответствии с Creative Commons Attribution 4.0 International License 